\title{
THE EFFECT OF BREED, BOAR AND SEASON ON SOME PROPERTIES OF SPERM
}

\author{
R. Savić1, M. Petrović1 ${ }^{1}$ D. Radojković ${ }^{1}$, Č. Radović 2 , N. Parunović ${ }^{3}$ \\ ${ }^{1}$ University of Belgrade - Faculty of agriculture, 11080, Belgrade- Zemun, Republic of Serbia \\ ${ }^{2}$ Institute for Animal Husbandry, 11080, Belgrade- Zemun, Republic of Serbia \\ ${ }^{3}$ Institute of Meat hygiene and Technology, 11000, Belgrade, Republic of Serbia \\ Corresponding author: savic@agrif.bg.ac.rs \\ Original scientific paper
}

Abstract: The main objective of this study was to assess the phenotypic variability of the ejaculate volume (VOL) and progressive sperm motility (MO) under the influence of breed, boar within breed and season. The study included 555 ejaculates of Danish Landrace (DL), Danish Large White (DLW) and Danish Duroc (DD) boars. The effect of boar was analyzed within the investigated breeds. The impact of the season was investigated as the influence of the month in which the ejaculate was taken. The model included a linear regression effect of boar age when the semen was taken. Data analysis was performed using the statistical package SAS 9.1.3 (SAS Inst. Inc.., 2002-2003). Impact assessment was carried out using the GLM procedure. The impact of all factors analyzed in both sperm traits was significant to highly significant, and the observed factors largely explain the phenotypic variability VOL compared to MO. The highest values were found in VOL of DL boar $(3: 58 \pm 164.96 \mathrm{ml})$, and the MO of boar breed DLW (85.45 \pm $0.94 \%$ ). Boars DD had VOL and MO below the averages of all analyzed breeds. Between boars within studied genotypes differences were established $(p<0.05, p$ $<0.05, \mathrm{p}<0.01 \mathrm{p}<0.001)$ and a boar of DLW breed compared to all tested boars had the highest volume of ejaculate sperm with progressive motility of $90.47 \%$. Volume, or mobility varied ( $<<0.01$ or $\mathrm{p}<0.05$ ) influenced by season, and in September and October boars had ejaculates with the VOL values above average and the lowest MO. Since most VOL and MO above the annual average in June, it was possible to get the highest number of doses per ejaculate with optimal reproductive/fertile ability.

Key words: sperm, boars, breed, season, volume, mobility 


\section{Introduction}

When speaking of the reproductive efficiency in swine production, one of the critical points is the knowledge of boar fertility. Success in implementing the technology of artificial insemination depends on the identification and selection of boars whose reproductive performance, evaluated on the basis of libido, performance in insemination and semen quality, are above average (Okere et al., 2005).

Fertility of boars can be seen through various quantitative and qualitative characteristics of sperm that determine its fertile ability. To produce high quality sperm of high genetic merit is the most important goal for artificial insemination centres (Frangež et al., 2005). Control of qualitative and quantitative traits of boar semen has great economic importance for pig breeders (Smital, 2010).

Ejaculate volume and progressive motility of sperm are important characteristics that determine the number of doses produced per ejaculate and reproductive ability of sperm. Estimated sperm motility is the most important parameter of sperm (Kunowska-Slósarz and Makowski 2011). Precise determination of volume, concentration and the percentage of live sperm is very important for the assessment of the maximum dilution of sperm that can be used for artificial insemination, and the number of sows that can be inseminated (Kanokwan, 2011).

Production of sperm varies throughout the year and depends on various endogenous and exogenous factors (Kondracki et al., 2009). The variability of these traits is influenced by breed, season, age of boar when the ejaculate was taken, the frequency of use of boars and other factors (Stančić et al., 2003 Frangež et al., 2005; Okere et al., 2005; Wolf and Smital, 2009 ; Smital and Wolf, 2009b; Smital, 2010). Research results of Kunowska-Slósarz and Makowska (2011) showed a significant effect of season and breed on the volume, concentration and number of live sperm in boar ejaculates.

The aim of this study was to determine how breed, season and age of boars affect the phenotypic variability of ejaculate volume and progressive motility of sperm.

\section{Material and methods}

The study included a total of 555 ejaculates from 10 boars. Table 1 shows the structure of the data set according to analyzed breeds. 
Table 1. Structure of the data set per breeds

\begin{tabular}{|l|c|c|c|c|}
\hline \multirow{2}{*}{ Variable } & \multicolumn{3}{|c|}{ Breeds } & \multirow{2}{*}{ All breeds } \\
\cline { 2 - 4 } & DL & DLW & DD & \\
\hline Number of ejaculates & 150 & 311 & 94 & 555 \\
\hline Average number of ejaculates per boar & 75.00 & 51.83 & 47.00 & 55.50 \\
\hline
\end{tabular}

DL-Danish Landrace, DLW- Danish Large White, DD- Danish Duroc

The data on the volume of ejaculate (VOL, ml) and progressive sperm motility $(\mathrm{MO}, \%)$ of boars was used. Ejaculate volume was measured with an accuracy of $\pm 10 \mathrm{ml}$, and assessment of progressive sperm motility was performed by a subjective method, observing native sperm sample under a microscope with a standard magnification (visual score). When it comes to the MO, there were no limits, so the research included all MO values from 0 to $100 \%$. Boars with less than five ejaculates were excluded from the analysis, the average number of ejaculates per boar was 55.50. The effect of boar was analyzed within the investigated breeds. The impact of the season was seen as the influence of the month in which the sperm is taken.

Data analysis was performed using the statistical package SAS 9.1.3 (SAS Inst. Inc.., 2002-2003). Impact assessment was carried out using the GLM procedure. We used the following mathematical-statistical model:

$$
\mathrm{Y}_{i j k l}=\mu+\mathrm{G}_{i}+\mathrm{G}(\mathrm{B})_{i j}+\mathrm{S}_{k}+\mathrm{b}\left(x_{i j k l}\right. \text {-Error! Bookmark not }
$$

defined.Error! Bookmark not defined.Error! Bookmark not defined.Error!

Bookmark not defined. $\left.\bar{x}_{i j k l}\right)+\varepsilon_{i j k l}$,

where: $\mathrm{Y}_{i j k l}$ - observed sperm trait, $\mu$ - general population average, $\mathrm{G}_{i-}$ the effect of breed $(i=1,2,3), \mathrm{G}(\mathrm{B})_{i j}$ - the effect of boar within the breed, $\mathrm{S} k$ - the effect of season $(k=1,2,3, \ldots, 12), \quad b \quad\left(x_{i j k l}\right.$-Error! Bookmark not defined.Error! Bookmark not defined.Error! Bookmark not defined.Error! Bookmark not defined. $\left.\bar{x}_{i j k l}\right)$ - linear regression effect of the age of boar when ejaculate was taken and $\varepsilon_{i j k l^{-}}$random error. Testing (comparing) of differences in LSMean values was done using the t- test.

\section{Results and Discussion}

Table 2 presents the basic statistical parameters of analyzed sperm characteristics. The average volume of examined ejaculate was $156.11 \mathrm{ml}$, and the 
average progressive motility of spermatozoa was $84.22 \%$. Ejaculate volume showed a greater absolute and relative variation $(59.59 \mathrm{ml}$ and $38.17 \%$ ) compared with progressive sperm motility $(15.30 \mathrm{ml}$ and $18.17 \%)$. Among the observed characteristics of sperm correlation coefficient showed a weak positive correlation $\left(0.365^{* * *}\right)$. The average age of the boar when the ejaculate was taken was 628.58 days.

Table 2. Basic statistical parameters

\begin{tabular}{|l|c|c|c|c|}
\hline Traits & $\overline{\mathrm{X}}$ & $\mathrm{SD}$ & $\mathrm{CV}$ & $\mathrm{r}$ \\
\hline VOL, ml & 156.11 & 59.59 & 38.17 & \multirow{2}{*}{$0.365^{* * *}$} \\
\cline { 1 - 4 } MO, \% & 84.22 & 15.30 & 18.17 & - \\
\hline ABE, day & 628.58 & 249.30 & 39.66 & - \\
\hline
\end{tabular}

X- Mean; SD- Standard deviation; CV- Coefficient of Variations; $r$ - Correlation Coefficents; VOLVolume of ejaculates; MO- Progressive motility; ABE- Average of age of the boar with ejaculate

The volume of ejaculate in this study was lower in comparison to the survey by Kunowska-Slósarz and Makowska (2011), and the progressive motility was higher. Established progressive motility $(84.22 \%)$ was higher compared to the survey by Stančić et al. (2003), who obtained value of 78\%, Frangež et al. (2005) who found values of 70.17 to $78.04 \%$ depending on the frequency of taking sperm. The reason for higher values of MO in this study may be due to the subjectivity in the visual assessment of sperm motility in the ejaculate.

The statistical significance of the factors included in the model are shown in Table 3. All analyzed factors showed significant to highly significant impact on the observed properties of the sperm. The influence of breed on the VOL and MO was highly significant $(\mathrm{F}=49.46 * * *, \mathrm{~F} * * *=15: 26)$, while the season had highly statistically significant, and significant effect on sperm traits $(\mathrm{F}=2: 54$ and $\mathrm{F} * *=$ $1.99 *$ ). Ejaculate volume and progressive motility of spermatozoa in the ejaculate varied among boars within the same breed $(\mathrm{p}<0.001)$.

Table 3. Effect of factors included in the model

\begin{tabular}{|c|c|c|c|c|}
\hline \multirow{3}{*}{ Factor } & \multicolumn{4}{|c|}{ Semen traits } \\
\hline & \multicolumn{2}{|c|}{ VOL } & \multicolumn{2}{|c|}{ MO } \\
\hline & $\mathrm{F}$ value & $\mathrm{R}^{2}$ & F value & $\mathrm{R}^{2}$ \\
\hline G (Breed) & $49.46 * * *$ & \multirow{4}{*}{0.511} & $15.26 * * *$ & \multirow{4}{*}{0.254} \\
\hline G(B) (Boars whitin breed) & $12.53 * * *$ & & $7.33 * * *$ & \\
\hline S (Seasone) & $2.54 * *$ & & $1.99 *$ & \\
\hline $\mathrm{b}$ (Age of boar) & $0.0985 * * *$ & & $0.0071 *$ & \\
\hline
\end{tabular}

VOL- Volume of ejaculates; MO- Progressive motility; $\mathrm{R}^{2}$ - Coefficient of determination 
Linear regression effect of boars age on the VOL was highly significant (b $=0.0985^{* * *}$ ) and regression coefficients showed that with increasing age, ejaculate and VOL increased also. VOL increase with increasing age of boars may be explained by the increase in mass and size of the testes, resulting in increased production of sperm. From the biological point of view, one of the reasons for increasing sperm production is to increase the number of Sertoli cells in the testes (Kanokwan, 2011). The regression coefficient for MO had a lower value ( $\mathrm{b}=$ $\left.0.0071^{*}\right)$, which indicates that as the age increases also MO increases, but compared to VOL, the dependence is significant at the level of $95 \%$. There is a tendency of increase of ejaculate volume and progressive sperm motility with increasing age of the boar, which is similar to the conclusions made by Stančić et al. (2003), Wolf and Smital (2009a), Wolf and Smital (2009b), Smital (2009), Banaszewska and Kondracki (2012).

The relevance of the observed factors indicate the need for continuing study of characteristics of boar sperm in selected pig populations, and taking appropriate steps to improve the properties or eliminating boars whose phenotypic traits of sperm are significantly below average. The calculated coefficients of determination showed that the analyzed effects to a greater extent explain the variability in ejaculate volume $\left(\mathrm{R}^{2}=0.511\right)$ compared to the progressive sperm motility $\left(\mathrm{R}^{2}=0.254\right)$.

This research is partially consistent with the research of Šerniene et al. (2002), as the above authors found that the seasons and the interaction of some factors had a significant effect on sperm motility. In contrast, breed and age of boars in studies of Šrniene et al. (2002) did not affect the variability of the characteristics of sperm. The results of our research on the impact of breed and season on VOL are similar to the research by Okere et al. (2005), and when it comes to the variability of MO, there are differences because seasonal effects in the study of these authors were not significant. Comparing with the research of Kondracki et al. (2009), the results of our study are similar, given that these authors found seasonal effects on the variability of the analyzed sperm characteristics. Age of boars showed a significant effect on sperm parameters (Smital, 2009), so our results are consistent with the research of this author. This research is consistent with the results of Smital (2010) in which all studied effects showed a significant effect on all traits of sperm $(\mathrm{p}<0.001)$.

In Table 4, LSMean values of boar semen according to the breeds included in the study, are presented. The values of VOL and MO in fertile breeds (DL and DLW) were above average. The largest volume of ejaculate was found in boars of breed DL $(164.96 \mathrm{ml})$, and the lowest in breed DD $(102.55 \mathrm{ml})$. The differences in the mean values of VOL between boar breeds DD and DL $(62.41 \mathrm{ml})$, DD and DLW $(61.34 \mathrm{ml})$ were statistically highly significant $(\mathrm{p}<0.001)$.

Boars of breed DLW had the highest progressive sperm motility $(85.45 \pm$ $0.94 \%$ ). In contrast to these, the least progressive motility of spermatozoa in the 
ejaculate had DD boars $(74.03 \pm 1.83 \%)$. The difference between the mean values of MO in boars DLW and DL (1.22\%) was not statistically significant $(\mathrm{p}>0,05)$. Boars of breeds DLW and DL had the higher mean sperm motility $(+11.42 \%$ and $+10.20 \%$ ) compared to boars of DD breed. The differences were very highly significant

Table 4. Effect of breeds on semen traits (LSMean \pm SE)

\begin{tabular}{|l|c|c|}
\hline \multirow{2}{*}{ Breeds } & \multicolumn{2}{|c|}{ LSMean \pm SE } \\
\cline { 2 - 3 } & VOL $(\mathrm{ml})$ & MO $(\%)$ \\
\hline DL & $164.96 \pm 3.58^{\mathrm{A}}$ & $84.23 \pm 1.14^{\mathrm{A}}$ \\
\hline DLW & $163.89 \pm 2.95^{\mathrm{A}}$ & $85.45 \pm 0.94^{\mathrm{A}}$ \\
\hline DD & $102.55 \pm 5.77^{\mathrm{B}}$ & $74.03 \pm 1.83^{\mathrm{B}}$ \\
\hline All breeds & $151.84 \pm 2.15$ & $82.92 \pm 0.68$ \\
\hline
\end{tabular}

DL- Danish Landrace; DLW- Danish Large White; DD- Danish Duroc; VO- Volume of ejaculates; MO- Progressive motility; A, B- Significant at level $p<0.001$

Contrary to the present study, Banaszewski and Kondracki (2012) found higher values of ejaculate volume in the studied breeds of boars (from $162.75 \pm$ 50.52 to $268.79 \pm 88.06 \mathrm{ml}$ ). The low value of the ejaculate volume of Duroc breed boars $(102.55 \pm 5.77 \mathrm{ml})$ found in this study is consistent with research by Stančić et al. (2003: $191 \mathrm{~mL})$, Wolf and Smital $(2009 \mathrm{~b} ; 200 \mathrm{ml})$, and Banaszewski and Kondracki $(2012 ; 162.75 \mathrm{ml}$ ). They found lower values of ejaculate volume in boars of Duroc breed compared to other breeds, but in our study, the mean value is lower. Unlike research by Okere et al. (2005), which determined the Yorkshire boars superiority compared to Landrace boars, in our study, differences in phenotypic values of VOL and MO between DL and DLW were not significant ( $>0,05)$. The results of this study are similar to research of Smital and Wolf (2009) who found slight difference between the breeds, where Czech Landrace had a larger volume of ejaculate, but all other traits of sperm had higher values in the Czech LW boars. The differences in sperm motility $(p \leq 0.01)$ in Polish Landrace compared to other tested breeds were determined in the study by KunowskaSlósarz and Makowska (2011).

Table 5 shows LSMean values of sperm traits per boars, and the significance of differences between boars within studied genotypes.

The volume of ejaculate of two DL boars was above the average of all tested boars, while the difference in MO between them was significant $(\mathrm{p}<0,05)$. The greatest VOL (from 115.39 to $196.36 \mathrm{ml}$ ) and MO (from 67.39 to $92.52 \%$ ) variation interval was within the breed DLW. The differences between boars DLW were significant to highly significant, indicating that in the selected pig populations it is necessary to monitor properties of sperm, in order to receive per each ejaculate a maximum doses for insemination of optimal reproductive ability. 
Table 5. Effect of boars within the breed on semen traits (LSMean \pm SE)

\begin{tabular}{|l|c|c|c|}
\hline \multirow{3}{*}{ Breeds } & $\begin{array}{c}\text { Identification number } \\
\text { of boars }\end{array}$ & \multicolumn{2}{|c|}{ LSMean \pm SE } \\
\cline { 2 - 4 } & 8330 & $169.83 \pm 4.60$ & MO $(\%)$ \\
\hline \multirow{3}{*}{ DL } & 8416 & $160.09 \pm 5.44$ & $86.75 \pm 1.46^{\mathrm{Aa}}$ \\
\cline { 2 - 4 } & 899 & $160.96 \pm 8.26^{\mathrm{A}, \mathrm{a}, \mathrm{Aa}}$ & $81.70 \pm 1.73^{\mathrm{Bb}}$ \\
\cline { 2 - 4 } & 926 & $158.60 \pm 5.60^{\mathrm{A}, \mathrm{a}}$ & $95.42 \pm 2.62^{\mathrm{A}, \mathrm{Aa}}$ \\
\cline { 2 - 4 } & 936 & $165.82 \pm 4.86^{\mathrm{A}, \mathrm{Aa}}$ & $87.38 \pm 1.90^{\mathrm{A}, \mathrm{Bb}}$ \\
\cline { 2 - 4 } & 1017 & $196.36 \pm 4.42^{\mathrm{B}}$ & $90.47 \pm 1.40^{\mathrm{A}, \mathrm{Aa}}$ \\
\cline { 2 - 4 } & 14448 & $115.39 \pm 11.50^{\mathrm{C}, \mathrm{b}}$ & $67.39 \pm 3.65^{\mathrm{B}}$ \\
\cline { 2 - 4 } & 35571 & $186.19 \pm 7.08^{\mathrm{A}, \mathrm{b}, \mathrm{Bb}}$ & $89.53 \pm 2.25^{\mathrm{A}}$ \\
\hline \multirow{4}{*}{ DD } & 1251 & $125.91 \pm 10.41^{\mathrm{A}}$ & $76.74 \pm 3.31$ \\
\cline { 2 - 4 } & 1314 & $79.20 \pm 4.90^{\mathrm{B}}$ & $71.33 \pm 1.55$ \\
\hline
\end{tabular}

DL- Danish Landrace; DLW- Danish Large White; DD- Danish Duroc; VO- Volume of ejaculates; MO- Progressive motility; A, B, C- Significant at level $\mathrm{p}<0.001$; a, b- Significant at level $\mathrm{p}<0.01$; Aa, Bb- Significant at level $\mathrm{p}<0.05$

Boar with identification number 1017 had the highest volume of ejaculate (196.36 ml) with high progressive motility (90.47\%). Comparison with the boar number 926, which had the ejaculates with the highest value of MO $(92.52 \%)$, the differences in mean values of MO $(2.05 \%)$ was not significant, but the VOL of ejaculates in boar 1017 was significantly higher $(+37.76 \mathrm{ml}, \mathrm{p}<0.001)$. Given the high mobility of sperm and determined differences of ejaculates, the boar with identification number 1017 can get the greatest number of doses for artificial insemination of optimal fertile ability. Boars DD had values below the average sperm characteristics, and differences in the VOL were highly significant $(\mathrm{p}$ $<0.001)$.

Effect of season on semen characteristics observed is shown in Table 6. If the value of ejaculate volume during the year is analyzed, the highest value was in the month of June $(166.03 \pm 6.60 \mathrm{ml})$, while the lowest VOL was during the month of May $(137.97 \pm 6.74 \mathrm{ml})$. Lower values of VOL, below the annual average $(151.84 \pm 02.15 \mathrm{ml})$ can be observed in January-May Low values during winter may be due to the negative impact of low temperatures in the facilities where boars are kept. At the same time the ejaculate mobility was above average.

September and October are characterized with semen ejaculate volumes above average, but the lowest progressive motility. In September and October spematozoid progressive motility was the lowest (78.47 and 78.63\%), which can be explained as a result of the high temperatures during the summer period and the occurrence of chronic stress caused by the stress factor during the autumn period. 
In the subsequent months a trend of gradual increase can be observed and overcoming of the consequences of heat stress.

Table 6. Effect of season on semen traits $($ LSMean \pm SE)

\begin{tabular}{|l|c|c|}
\hline \multirow{2}{*}{ SEZ } & \multicolumn{2}{|c|}{ LSMean \pm SE } \\
\cline { 2 - 3 } & VOL $(\mathrm{ml})$ & MO (\%) \\
\hline 1 & $141.59 \pm 6.54$ & $84.92 \pm 2.08$ \\
\hline 2 & $146.67 \pm 6.42$ & $85.31 \pm 2.04$ \\
\hline 3 & $139.97 \pm 6.17$ & $85.81 \pm 1.96$ \\
\hline 4 & $141.28 \pm 6.59$ & $85.28 \pm 2.09$ \\
\hline 5 & $137.97 \pm 6.74$ & $84.54 \pm 2.14$ \\
\hline 6 & $166.03 \pm 6.60$ & $84.76 \pm 2.09$ \\
\hline 7 & $157.12 \pm 6.87$ & $80.60 \pm 2.18$ \\
\hline 8 & $156.28 \pm 7.80$ & $80.28 \pm 2.48$ \\
\hline 9 & $165.80 \pm 6.39$ & $78.47 \pm 2.03$ \\
\hline 10 & $160.47 \pm 6.08$ & $78.63 \pm 1.93$ \\
\hline 11 & $156.18 \pm 5.49$ & $81.36 \pm 1.74$ \\
\hline 12 & $152.68 \pm 6.04$ & $85.09 \pm 1.92$ \\
\hline Average & $151.84 \pm 2.15$ & $82.92 \pm 0.68$ \\
\hline
\end{tabular}

SEZ- Season; VOL- Volume of ejaculates; MO- Progressive motility

September and October are characterized with semen ejaculate volumes above average, but the lowest progressive motility. In September and October spematozoid progressive motility was the lowest (78.47 and $78.63 \%$ ), which can be explained as a result of the high temperatures during the summer period and the occurrence of chronic stress caused by the stress factor during the autumn period. In the subsequent months a trend of gradual increase can be observed and overcoming of the consequences of heat stress.

The results of comparisons between months are shown in Table 7. VOL was the highest during the month of June, and the differences with respect to all months with lower values of VOL (January-May) were significant to highly significant. Since the highest VOL and MO are above the annual average in June, it was possible to get the highest number of doses per ejaculate with optimal reproductive ability. In comparison to other months the differences were not statistically significant. Comparing the months September and October, when the lowest values of MO were determined, with a period of higher values of $\mathrm{MO}$ (December-June), the differences were significant to highly significant. 
If VOL is compared, the results of this study are similar to investigations by Okere et al. (2005), Kondracki et al. (2009), Wolf and Smital (2009), which have established in the spring, the lowest volume of ejaculate in the investigated breeds. Comparing the results of Kunowska-Slósarz and Makowska (2011), the results of this study are partly similar, given that in the study of these authors in the period January-June, VOL value below the annual average and above-average values from August to December were established, while for MO, the lowest values were established in the October-December period and June-July period and a maximum in January-May and August-September.

Table 7. Results of the t- test for LSMean values for seasonal effect

\begin{tabular}{|c|c|c|c|c|c|c|c|c|c|c|c|c|}
\hline SEZ & 1 & 2 & 3 & 4 & 5 & 6 & 7 & 8 & 9 & 10 & 11 & 12 \\
\hline 1 & - & $\mathrm{ns}$ & $\mathrm{ns}$ & $\mathrm{ns}$ & $\mathrm{ns}$ & $*$ & $\mathrm{~ns}$ & $\mathrm{~ns}$ & $*$ & $*$ & $\mathrm{~ns}$ & $\mathrm{~ns}$ \\
\hline 2 & $\mathrm{~ns}$ & - & $\mathrm{ns}$ & $\mathrm{ns}$ & $\mathrm{ns}$ & $*$ & $\mathrm{~ns}$ & $\mathrm{~ns}$ & $*$ & $\mathrm{~ns}$ & $\mathrm{~ns}$ & $\mathrm{~ns}$ \\
\hline 3 & $\mathrm{~ns}$ & & - & $\mathrm{ns}$ & $\mathrm{ns}$ & $*$ & $\mathrm{~ns}$ & $\mathrm{~ns}$ & $*$ & $*$ & $*$ & $\mathrm{~ns}$ \\
\hline 4 & $\mathrm{~ns}$ & $\mathrm{~ns}$ & $\mathrm{~ns}$ & - & $\mathrm{ns}$ & $\mathrm{n}$ & $\mathrm{ns}$ & $\mathrm{ns}$ & $*$ & $*$ & $\mathrm{~ns}$ & $*$ \\
\hline 5 & $\mathrm{~ns}$ & $\mathrm{~ns}$ & $\mathrm{~ns}$ & $\mathrm{~ns}$ & - & $*$ & $\mathrm{n}$ & $\mathrm{ns}$ & $*$ & $*$ & $\mathrm{n}$ & $\mathrm{ns}$ \\
\hline 6 & $\mathrm{~ns}$ & $\mathrm{~ns}$ & $\mathrm{~ns}$ & $\mathrm{~ns}$ & & - & $\mathrm{ns}$ & $\mathrm{ns}$ & $\mathrm{ns}$ & $\mathrm{ns}$ & $\mathrm{ns}$ & $\mathrm{ns}$ \\
\hline 7 & $\mathrm{~ns}$ & $\mathrm{~ns}$ & $\mathrm{~ns}$ & $\mathrm{~ns}$ & $\mathrm{~ns}$ & $\mathrm{~ns}$ & - & $\mathrm{ns}$ & $\mathrm{ns}$ & $\mathrm{ns}$ & $\mathrm{ns}$ & $\mathrm{ns}$ \\
\hline 8 & $\mathrm{~ns}$ & $\mathrm{~ns}$ & $\mathrm{~ns}$ & $\mathrm{~ns}$ & $\mathrm{~ns}$ & $\mathrm{~ns}$ & $\mathrm{~ns}$ & - & $\mathrm{ns}$ & $\mathrm{ns}$ & $\mathrm{ns}$ & $\mathrm{ns}$ \\
\hline 9 & $*$ & $*$ & $* *$ & $*$ & $*$ & $*$ & $\mathrm{~ns}$ & $\mathrm{~ns}$ & - & $\mathrm{ns}$ & $\mathrm{ns}$ & $\mathrm{ns}$ \\
\hline 10 & $*$ & $*$ & $* *$ & $*$ & $*$ & $*$ & $\mathrm{~ns}$ & $\mathrm{~ns}$ & $\mathrm{~ns}$ & - & $\mathrm{ns}$ & $\mathrm{ns}$ \\
\hline 11 & $\mathrm{~ns}$ & $\mathrm{~ns}$ & $\mathrm{~ns}$ & $\mathrm{~ns}$ & $\mathrm{~ns}$ & $\mathrm{~ns}$ & $\mathrm{~ns}$ & $\mathrm{~ns}$ & $\mathrm{~ns}$ & $\mathrm{~ns}$ & - & $\mathrm{ns}$ \\
\hline 12 & $\mathrm{~ns}$ & $\mathrm{~ns}$ & $\mathrm{~ns}$ & $\mathrm{~ns}$ & $\mathrm{~ns}$ & $\mathrm{~ns}$ & $\mathrm{~ns}$ & $\mathrm{~ns}$ & $*$ & $*$ & $\mathrm{~ns}$ & - \\
\hline
\end{tabular}

SEZ- Season; $n s-\mathrm{p}>0.05 ;{ }^{*}-\mathrm{p}<0.05 ;{ }^{* *}-\mathrm{p}<0.01$; Testing the difference of the LSMean values between months for trait VOL shown above, and for trait MO shown below the diagonal

In the study by Šrniene et al. (2002), the highest motility was found during autumn and winter (84.55 and $85.79 \%$ ) and lowest during summer (78.48\%), so that the results of this study are partially similar to the results of the present study. Reduced sperm motility in this study in September and October, is partially similar to the results of research by Stancić et al. (2003) since in the study of these authors progressive motility was the lowest in the October-December period (75\%), and highest in July-September (86\%).

\section{Conclusion}

Ejaculate volume and sperm progressive motility are important characteristics that determine the number of doses produced per ejaculate and reproductive ability of sperm. Both sperm characteristics vary significantly to the 
highly significantly under the influence of breed, boar within breed and season. Linear regression coefficients indicate that as the age of the boar when the ejaculate is taken increases, VOL $(b=0.0985, p<0.001)$ and MO $(b=0.0071, p$ $<0,05)$ increase. The analyzed factors largely explain the variability of VOL compared to MO.

There are differences between the breeds in terms of phenotypic values of both sperm traits analyzed and also significant differences $(p<0.001)$ between fertile breed (DL and DLW) compared to the very meaty breed DD were established.

Both observed properties of sperm varied under the influence of boar within studied genotypes, and there were differences $(\mathrm{P}>0.05, \mathrm{p}<0.05, \mathrm{p}<0.01 \mathrm{p}$ $<0.001$ ), indicating that in the selected swine populations sperm characteristics should be monitored in order to get as many insemination doses with optimal reproductive ability per ejaculate.

Effect of season on the VOL was highly significant ( $<<0.01)$, while the MO statistically significantly varied under the influence of the same factor. In September and October, semen samples had values of VOL above average, but the lowest progressive motility. Low values of MO in this period are due to the high temperatures during the summer period and the occurrence of chronic stress. This indicates the need for adequate microclimate conditions in the facilities where boars are kept, so that the temperature fluctuations during the year could be reduced to a minimum.

\title{
Acknowledgment
}

Research was financed by the Ministry of Education and Science Republic of Serbia, project TR 31081.

\section{Uticaj rase, nerasta i sezone na neke osobine sperme}

\author{
R. Savić, M. Petrović, D. Radojković, Č. Radović, N. Parunović
}

\section{Rezime}

Osnovni cilj rada bio je da se oceni fenotipska varijabilnost volumena ejakulata (VOL) i progresivne pokretljivosti spermatozoida (MO) pod uticajem rase, nerasta unutar rase i sezone. Istraživanjem je bilo obuhvaćeno 555 ejakulata nerasta rase danski landras (DL), danski jorkšir (DLW) i danski durok (DD). Uticaj nerasta analiziran je unutar ispitivanih rasa. Uticaj sezone ispitivan je kao uticaj 
meseca u kojem je uzet ejakulat. U model je uključen i linearni regresijski uticaj starosti nerasta prilikom uzimanja ejakulata. Obrada podataka izvršena je pomoću statističkog paketa SAS 9.1.3 (SAS Inst. Inc., 2002-2003). Ocena uticaja je izvršena primenom GLM procedure. Uticaj svih analiziranih faktora na obe osobine sperme bio je značajan do vrlo visoko značajan, a posmatrani faktori u većoj meri objašnjavaju fenotipsku varijabilnost VOL u odnosu na MO. Najveće vrednosti VOL utvrđene su kod nerasta rase DL $(164.96 \pm 3.58 \mathrm{ml})$, a MO kod nerasta rase DLW (85.45 $\pm 0.94 \%)$. Nerasti DD imali su VOL i MO ispod proseka svih analiziranih rasa. Između nerasta unutar ispitivanih genotipova utvrđene su razlike ( $>00.05, p<0.05, p<0.01, p<0.001$ ), a nerast rase DLW $u$ odnosu na sve ispitivane neraste imao je najveći volumen ejakulata sa progresivnom pokretljivošću spermatozoida od $90.47 \%$. Volumen, odnosno pokretljivost su varirali $(\mathrm{p}<0.01$, odnosno $\mathrm{p}<0.05$ ) pod uticajem sezone, a u periodu septembar-oktobar nerasti su imali ejakulate sa vrednostima VOL iznad proseka i najnižom MO. S obzirom na najveći VOL i MO iznad godišnjeg proseka, u junu mesecu je bilo moguće dobiti najveći broj doza po ejakulatu sa optimalnom fertilnom sposobnošću.

\section{References}

BANASZEWSKA D., KONDRACKI S. (2012): An assessment of the breeding maturity of insemination boars based on ejaculate quality changes. Folia Biologica (Kraków), 60, No 3-4, 151-162.

FRANGEŽ R., GIDER T., KOSEC M. (2005): Frequency of boar ejaculate collection and its influence on semen quality, pregnancy rate and litter size. Acta vet. Brno, 74, 265-273.

KANOKWAN K. (2011): Association and expression study of CD9, PLCz and COX-2 as candidate genes to improve boar sperm quality and fertility traits. Institut für Tierwissensechaften, Abt. Tierzucht und Tierhaltung der Rheinischen Friedrich-Wilhelms- Universität Bonn. Inaugural-Dissertation.

KONDRACKI S., WYSOKIŃSKA A., KOWALEWSKI D., MUCZYŃSKA E., ADAMIAK A. (2009): Season's influence on the properties of male domestic pig semen. Rozprawy naukowe Pope John Paul II State School of Higher Vocational Education in Biała Podlaska, Vol. III, 177-187.

KUNOWSKA-SLÓSARZ M., MAKOWSKA A. (2011): Effect of breed and season on the boar's semen characteristics. Annals of Warsaw University of life sciences- SGGW, Animal Science, 49, 77-86.

OKERE C., JOSEPH A., EZEKWE M. (2005): Seasonal and genotype variations in libido, semen production and quality in artificial insemination boars. Journal of animal and veterinary advances, 4, 10, 885-888.

SAS INST. INC. (2002-2003): The SAS System for Windows, Cary, NC. 
SMITAL J. (2009): Effects influencing boar semen. Animal reproduction, 110, 3, 335-346. (abstract)

SMITAL J. (2010): Comparison of environmental variations in boar semen characteristics of six breeds and their crossbreds over an eight-year period. Research in pig breeding, 4, 1, 26-32.

STANČIĆ B., GAGRČIN M., RADOVIĆ I. (2003): Uticaj godišnje sezone, rase i starosti nerastova na kvalitet sperme (1. Nativna sperma). Biotechnology in animal husbandry, 19, 1-2, 17-23.

ŠERNIENÉ LORETA, RIŠKEVIČIENÉ VITA, BANYS ANTANAS, ŽILINKAS HENRIKAS (2002): Effects of age, and season on sperm qualitative parameters in Lithuanian white and Pietren boars. Veterinarija ir zootechnika, 17 (39).

WOLF J., SMITAL J. (2009a): Effects in genetic evaluation for semen traits in Czech large white and Czech landrace boars. Czech J. Anim. Sci., 54, 8, 349-358.

WOLF J., SMITAL J. (2009b): Quantification of factors affecting semen traits in artificial insemination boars from animal model analyses. Journal of animal science, 87, 1620-1627.

Received 17 June 2013; accepted for publication 28 June 2013 